\title{
住宅の床仕上げ構造の振動応答特性と床衝撃音遮断性能との関係 RELATION BETWEEN VIBRATION RESPONSE CHARACTERISTICS IN RESIDENTIAL FLOOR FINISH STRUCTURE AND FLOOR IMPACT SOUND INSULATION PERFORMANCE
}

\author{
渡辺秀夫*1, 木村 翔*2, 井上勝夫*3, 石井 健太郎*4 \\ Hideo WATANABE, Sho KIMURA, Katsuo INOUE \\ and Kentaro ISHII
}

\begin{abstract}
In regard to the concrete slab skeleton, the method of prediction for floor impact sound level has been established from the analysis results of vibration responses focussing on impedance, which is widely utilized at the present time.

In this paper, in regard to residential floor finish structure, we describe the results of the experiment on dynamic displacement and dynamic spring coefficients by using a footstep impact simulator, on impact duration by using a tapping hammer, on point impedance by using an impulse hammer and on reduction of floor impact sound level, in order to classify the floor finish structure from the vibration response characteristics and to establish the method of prediction of the reduction by using the relationship between vibration response characteristics and floor impact sound insulation performance.
\end{abstract}

\section{keyword : residential floor, vibration characteristics, point impedance, displacement response characteristics}

住宅床、振動特性、駆動点インピーダンス、変位応答特性

\section{1.はじめに}

集合住宅においては、温熱・空気環境、音環境、照明視環境など さまざまな環境に関する居住性能が要求される。そのうち、音環境 では、床衝撃音、室間遮音、空遮音、給排水騒音等があるが、その 中で最も不満の多い項目として居住者の指摘率が高いのが、床衝撃 音となっている。床に求められる要求性能としては、床衝撃音遮断 性能のほかに、すべり防止、熱的性能、耐水性能、耐摩耗性能、耐 衝撃性能、感触・歩行感といったものがあげられるが、床衝撃音遮 断性能は、他住戸へ大きな影響を与えるという点からみて、特に重 要な性能の一つとなっている。

床衝撃音に関しては、数多くの実験研究が行われてきており、そ の成果が実際の設計に活かされて、音環境の居住性能は着実に向上 してきている。また、最近の設計においては、床スラブの厚さは、構 造的な要因からではなく、床衝撃音レベルの性能要求の遮音等級を クリアさせるために、床衝撃音遮断性能の面から決定される場合も 多くなっており、設計施工サイドの意識も高まってきている。しか し、それと同時に居住者の質的な要求度が嚼しくなってきているた め、居住者の不満度は、依然として高い比率になっているのが実状 である。一方では、住宅の性能表示制度が施行される方向で検討が 進んでおり、実際と対忍した床衝撃音遮断性能の予測に対する精度
を向上させることが強く求められている。

これまで、床衝撃音遮断性能に関する研究は、コンクリート造集 合住宅の躯体構造を中心に行われてきており、床衝撃時のコンク リートスラブのインピーダンスに着目した振動応答特性の解析結果 から、インピーダンス法として床衝撃音レベルの予測法が確立され、 現在広く活用されている ${ }^{122)}$ 。その後、木質系住宅や鉄骨系住宅の床 構造についても、インピーダンスによる解析が行われ、床衝撃音遮 断性能向上のための多くの提案がなされている314)。

しかし、実際の床衝撃音は、躯体構造のみではなく、上部構造で ある床仕上げ構造の影響も大きく受け、床衝撃音レベルを左右する 重要な要因となる。休仕上げ構造の床衝撃音特性に関しては、安岡 によって理論的解析が行われているが5)、実際の床仕上げ構造の床 衝撃音レベル低減量については、実験室や現場における実測データ から把握されることが多く、床仕上げ構造の振動応答特性から得ら れる物理量に基づく検討はあまり行われていないのが現状である。

そこで、本報では、床仕上げ構造の動的振動応答特性から実衝撃 源に対する床衝撃音の発生系を明らかにし、その性能向上のための 検討や予測方法を確立していく必要があると考え、住宅の各種床仕 上げ構造について、上部構造としての振動応答を測定し、その振動 応答特性からみた床仕上げ構造の分類と、上部構造の動的振動応答
*1 巨田建設技術研究所 工修

*2 日本大学理工学部 教授・工博

*3 日本大学理工学部 助教授.工博

*4 竹中工務店 (元目本大学大学院·工修)
Technical Research Institute, Toda Corp., M. Eng.

Prof., College of Science and Technology, Nihon Univ., Dr. Eng.

Assoc. Prof., College of Science and Technology, Nihon Univ., Dr. Eng.

Takenaka Corp., M. Eng. 
特性から得られる諸物理量と床衝撃音レベル低减量との関係につい て検討を行った。

床仕上げ構造の床衝撃音レベル低减量に関係すると考えられる動 的振動応答物理量は、動的ばね定数、衝撃周波数、衝撃インピーダ ンスレベル、全時間応答インピーダンス周波数特性などがあげられ る。そこで、振動応答物理量として、歩行シミュレータを用いて歩 行時の踵部波形に対応した衝撃を加えた場合の動的変位量、タッピ ングハンマーによる衝撃時間、インパルスハンマーによる駆動点イ ンピーダンスの測定を行い、これらの測定データを基にして、動的 ばね定数、衝撃周波数、衝撃インピーダンスレベル、全時間応答イ ンピーダンス周波数特性を求めて、床衝撃音レベル低減量との関係 について考察を行った。本報で取り扱う振動応答物理量と床衝撃音 レベル低減量との関連を整理して図 1 に示す。

なお、床仕上げ構造の床衝撃音遮断性能の向上が期待できるの は、基本的には軽量床衝撃音を対象にした場合であるため、本報で は、主として軽量床衝撃音レベル低減量を中心にして検討を行った。

\section{2. 実験の概要}

\section{1 実験対象の床仕上げ構造}

実験対象とした床仕上げ構造は、コンクリートスラブ上に施エさ れる床仕上げ構造として、現在広く使用されている直張木質フロー リング床 9 体、根太床 6 体、乾式二重床 6 体、畳床 5 体、カーペッ ト床 5 体の計 31 床仕上げ構造である。試験体の概要を表 1 に示す。

根太床 $(\mathrm{N}-1 \sim \mathrm{N}-6)$ は、根太間隔や根太断面寸法、板厚等を変え て曲げ剛性等に変化をもたせた仕様とし、乾式二重床は、防振ゴム 置床（B-1〜B-4）と発泡プラスチック下地床（H-1〜H-2）の 2 種 類である。図 2 に乾式二重床の断面図を示す。直張木質フローリン グ床（F-1～F-9）は、軽量衝撃源に対する公称遮音等級でL-40〜 60 のもののほかに、緩衝材なしのボードのみの床材 (F-2) も試験 体の一つとした。畳床 (T-1〜T-5) は本畳と化学畳の 2 種類とした。 $\mathrm{T}-1$ の 4 層化学畳は、3 層化学疊を基調として、表面は $10 \mathrm{~mm}$ 厚さの わらで構成された構造となっている。カーペット床 (C-1〜C-5) は ループ系およびカットパイル系のものから厚さの異なるものを選定
して、フェルト（厚さ $8 \mathrm{~mm}$ )を下地として施エした。

2.2 歩行衝撃シミュレータによる動的変位応答特性測定

動的変位応答特性の測定は、実際の歩行時の衝撃に対応した特性 をみるために、実歩行時で最も床衝撃音に影響すると考えられる踵 部の衝擊力波形(6)を入力することとし、衝撃力特性を高精度で再現 できる「歩行衝撃シミュレータ」アを用いて行った。入力した睡部の 衝撃力特性の例を図 3 に示す。変位応答の測定は、従来行っていた 衝撃近傍点の応答特性では、局部圧縮変形型の床の場合、その特徴 を正確に把握できないと考え、床仕上げ材を衝撃した際の衝撃直下 点の変位応答をとることとし、図 4 に示すようなアタッチメントを 使用して、図 5 に示すブロックダイアグラムによりレーザー変位計 を用いて行った。なお、根太床や乾式二重床の衝搫位置は、振動が 発生しやすい根太間大引間や支持脚の中間点とした。

2.3 インパルスハンマーによる駆動点インピーダンス測定

駆動点インピーダンスの測定は、インパルスハンマー(衝翚周波

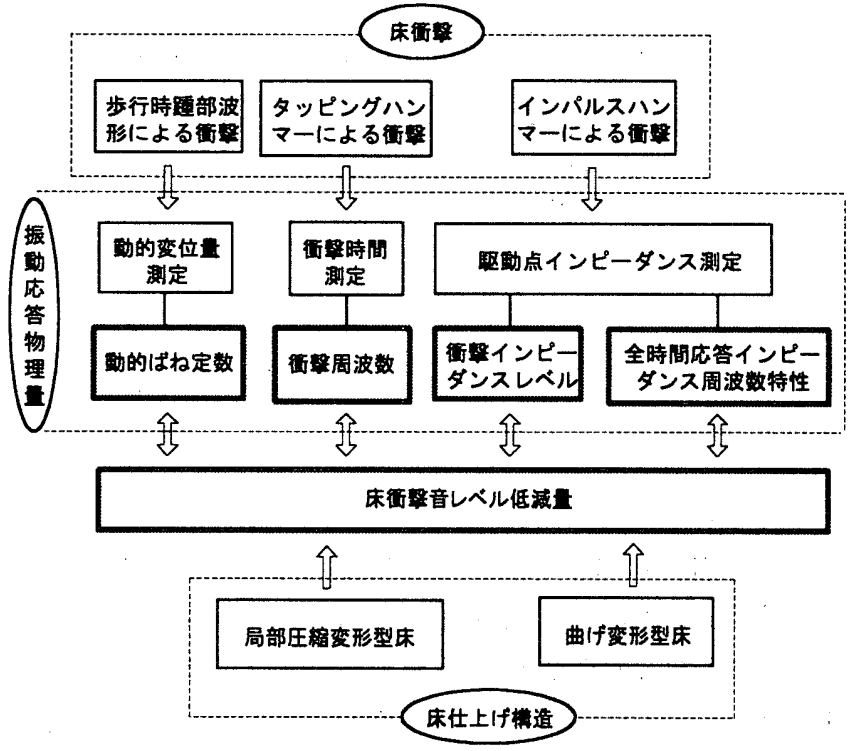

图 1 振動応答物理量と床㣫擊音レベル低隇量との関係

\section{表 1 試験体の概要}

\section{単位 : mm}

\begin{tabular}{|c|c|c|c|c|c|c|}
\hline & 上伐 & 㸮畐 & $6 \sqrt{61}$ & 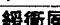 & $\operatorname{tn} i \lambda$ & 南和低: \\
\hline$F-1$ & $L-40$ & 14 & 9 & 5 & 0 & 0 \\
\hline$F-2$ & - & 15 & 15 & - & - & - \\
\hline $\mathrm{F}-3$ & $L-45$ & 12 & 8 & 4 & 0 & 0 \\
\hline$F-4$ & $L-60$ & 11 & 9 & 2 & 0 & 0 \\
\hline$F-5$ & $L-55$ & 9.5 & 7.5 & 2 & 0 & - \\
\hline$F-6$ & $L-50$ & 12 & 9 & 3 & 0 & 0 \\
\hline$F-7$ & $L-40$ & 14 & 9 & 5 & 0 & - \\
\hline$F-8$ & $L-45$ & 12 & 6 & 6 & & 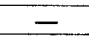 \\
\hline F-9 & -50 & 12 & 9 & & 8 & 8 \\
\hline
\end{tabular}

\section{根太床}

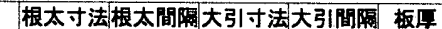

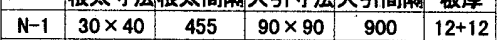
\begin{tabular}{|c|c|c|c|c|c|}
\hline$N-2$ & $34 \times 45$ & 303 & $90 \times 90$ & 900 & $15+15$ \\
\hline$N-3$ & $30 \times 40$ & 303 & $90 \times 90$ & 900 & $12+12$ \\
\hline
\end{tabular} \begin{tabular}{|l|l|l|l|l|l|}
$\mathrm{N}-3$ & $30 \times 40$ & 303 & $90 \times 90$ & 900 & $12+12$ \\
\hline
\end{tabular} \begin{tabular}{|c|c|c|c|c|c|}
$\mathrm{N}-4$ & $30 \times 40$ & 303 & $90 \times 90$ & 900 & 12 \\
\hline
\end{tabular} \begin{tabular}{|c|c|c|c|c|c|}
$\mathrm{N}-5$ & $30 \times 40$ & 600 & $90 \times 90$ & 900 & $12+9$ \\
\hline
\end{tabular} \begin{tabular}{l|l|l|l|l|}
$\mathrm{N}-6$ & $30 \times 40$ & 600 & $90 \times 90$ & 900 \\
\hline
\end{tabular} 〔注〕板里:表面材と下地材のボードLさ

\begin{tabular}{|c|c|c|c|c|}
\hline \multicolumn{5}{|c|}{ 郭式二重床 } \\
\hline & L值 & 板厚 & 支持点 & 1二外寸法 \\
\hline B-1 & $L-45$ & $12+12+20$ & 5 & $910 \times 910$ \\
\hline$B-2$ & - & $12+20$ & 4 & $600 \times 1200$ \\
\hline$B-3$ & $L-45$ & $12+12+25$ & 5 & $910 \times 910$ \\
\hline B-4 & $L-40$ & $14+12+25$ & 4 & $910 \times 910$ \\
\hline $\mathrm{H}-1$ & $L-50$ & 12 & - & - \\
\hline $\mathrm{H}-2$ & - & $12+12$ & - & - \\
\hline \multicolumn{5}{|c|}{ 〔注〕板厚: 表面材と下地材のボート厚さ } \\
\hline \multicolumn{5}{|l|}{ 葍床 } \\
\hline & & & 平 & 寸法 \\
\hline$T-1$ & & 賈化学要 & 55 & $910 \times 1820$ \\
\hline$T-2$ & & 害化学量 & 55 & $910 \times 1820$ \\
\hline$T-3$ & & 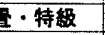 & 55 & $910 \times 1820$ \\
\hline$T-4$ & & 化学量 & 55 & $910 \times 1820$ \\
\hline$T-5$ & & - 2 級 & 55 & $910 \times 1820$ \\
\hline \multicolumn{5}{|c|}{ カーペット床 } \\
\hline & & & 緼厚 & 八伋厚 \\
\hline$c-1$ & \multicolumn{2}{|c|}{ HIGH\&LOHループ } & 8 & 6 \\
\hline$c-2$ & \multicolumn{2}{|c|}{ カットパイル } & 10 & 8 \\
\hline$c-3$ & \multicolumn{2}{|c|}{ レベルループ } & 9 & 7 \\
\hline$c-4$ & \multirow{2}{*}{\multicolumn{2}{|c|}{$\begin{array}{l}\text { レヘルループ } \\
\text { カットパイル }\end{array}$}} & 8 & 6 \\
\hline$c-5$ & & & 8.5 & 7 \\
\hline
\end{tabular}

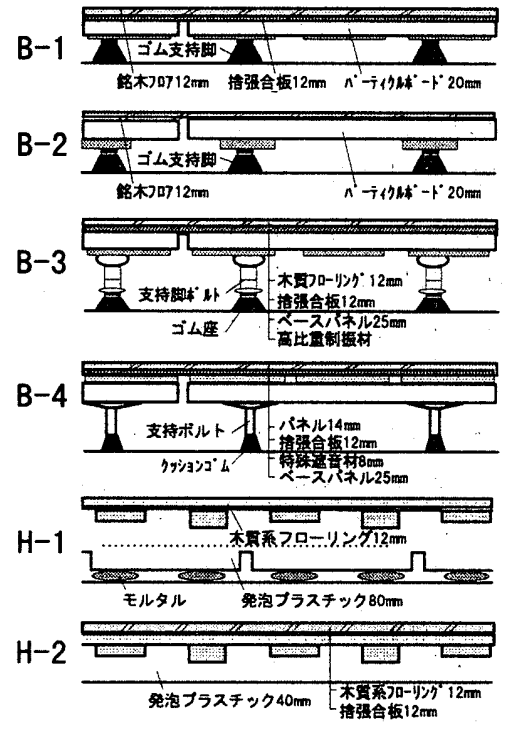

図 2 乾式二重床の断面図 
数 : 約 $80 \mathrm{~Hz})$ で衝撃したときの衝撃力 $(400 \sim 500 \mathrm{~N})$ と衝撃点近傍 の床仕上げ構造の振動速度応答の比から全時間応答の駆動点イン ピーダンスおよびハンマーの衝搫時間内の応答から衝撃インピーダ ンスを求めた。衝撃点は、動的変位応答特性を測定した位置と同様 である。図 6 に測定・解析ブロックダイアグラムを示す。

\section{4 タッピングハンマーによる衝撃時間測定}

衝撃時間の測定は、タッピングマシンの衝撃源と同じ0. $5 \mathrm{~kg}$ の質 量の鋼製タッピングハンマーを用いて、高さ $4 \mathrm{~cm}$ から単発自由落下 させ、ハンマー頂部に取り付けた振動ピックアップにより、衝撃時 の加速度応答波形を測定し、その波形から衝撃時間を読み取った。 なお、衝撃位置は、動的変位量、駆動点インピーダンス測定のとき と同じである。図 7 に測定・解析ブロックダイアグラムを示す。

2.5 床衝撃音レベル低隇量の測定

軽量床衝撃音レベル低减量は、各床構造の中から抽出した床につ いて、実験室 (コンクリートスラブ $140 \mathrm{~mm}$ ) において、JIS A 1440 に準拠し、タッピングマシンでスラブ素面とスラブ上に床材を施工 した床を衝撃したときの床衝撃音レベルを測定し、両者の差から低 減量を求めた。衝撃点は 3 点、受音点は 5 点とした。なお、重量床 衝撃音レベル低減量についても、同測定法に準じて測定した。

\section{3. 実験結果}

\section{1 動的変位量測定結果}

踵部の入力波形を用いて、ピーク衝撃力を $100 〜 700 \mathrm{~N} に$ 変化さ せたときの衝撃直下点における動的変位量測定結果を図 8 に示す。 これをみると、根太床、乾式二重床など曲げ変形が主体となる床仕 上げ構造は、衝撃力の増加とともに直線的に変位量が大きくなって いる。これに対して、直張木質フローリング床、睤床、カーペット 床は衝撃力によって变位量の増分が変化しており、直張木質フロー リング床は200〜300N、カーペット床は100～200N程度、また畳 床も300N以上の衝撃力で、増加が緩やかになる傾向がみられる。こ れは、それぞれの境界となっている衝撃力までは緩衝層や制振材の 柔らかいば称が支配的になっているのに対して、それ以上の衝撃力 になると床材が圧密され、断面全体としてかたくなるためと考えら れ、衝撃力によって、動的ばね定数が変化することを意味している。

この変位量の増加特性は、床衝撃音の発生系加らると、床仕上 げ材の効果として大きく影響し、床衝撃音の予測計算に対する床仕

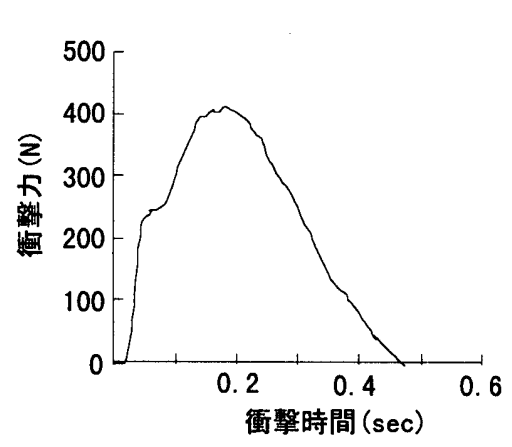

図3 踵部重撃力入力波形の例

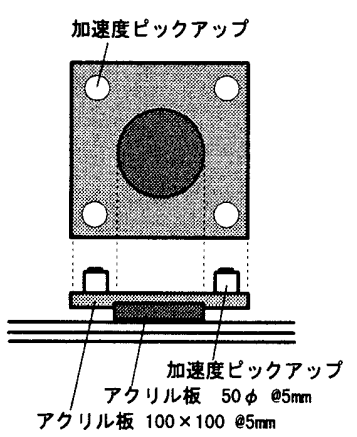

図4 衝撃直下点变位量測 定用アタッチメント

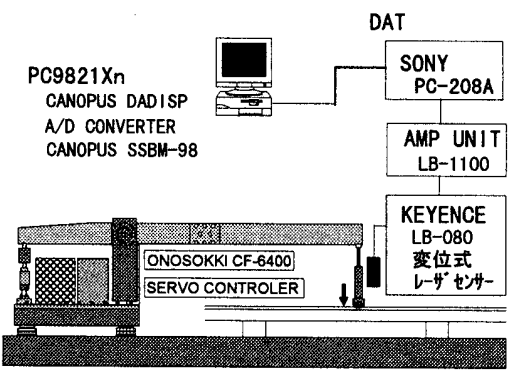

図 5 動的变位量測定·解析ブロックダイアグラム

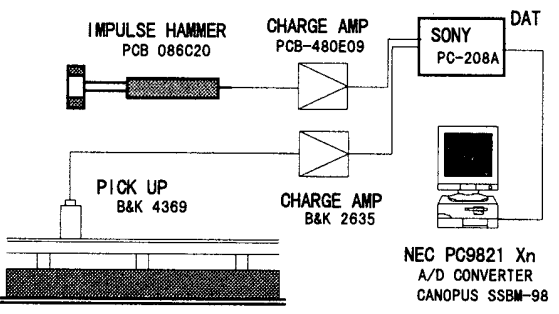

図6

駆動点インピーダンス測定·解析ブロックダイアグラム

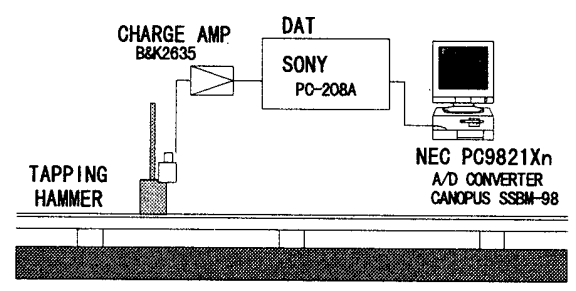

図 7 衝撃時間測定·解析ブロックダイアグラム
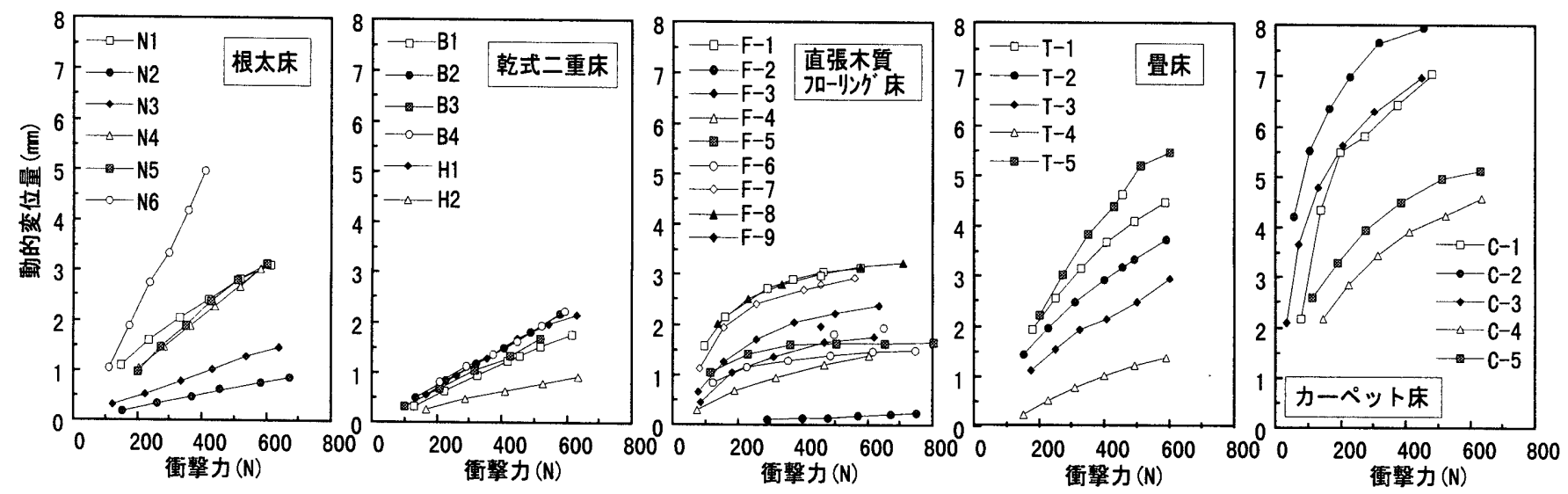

図 8 衝撃点直下における動的変位量測定結果 
上げ構造の影響算定等に当たっては、材料ごとの変位特性を十 分考慮する必要があることがわかる。

\section{2 動的ばね定数計算結果}

動的変位の増加量の割合が衝撃力によって変化することが明 らかとなったため、床衝撃音遮断性能と動的ばね定数との関係 を検討する場合、衝撃力に対応した動的ばね定数が必要になる と考えられる。そこで、動的ばね定数は、衝撃力の範囲を0〜 200N、300〜 700Nおよび0〜700Nの3つに分けて算出した。 その結果を図 9 に示す。また、衝撃力0～200Nのときのばね定 数を基淮にして、300〜 700Nおよび0〜700Nのときのばね定 数の比を求めた結果を図10に示す。

これらによると、根太床は、 $0.7 \times 10^{5} \sim 8.0 \times 10^{5} \mathrm{~N} / \mathrm{m} ま$ で変化しており、根太間隔、根太断面寸法から予測される床の 曲げ剛性に対応した大小関倸を示している。乾式二重床は、下 地材の発泡プラスチックを直にコンクリートに敷いているH-2 を除き $3.0 \times 10^{5} \mathrm{~N} / \mathrm{m}$ 前後のほぼ同じ值となっている。これら の床は、変位量が脚部の防振ゴムに依存するため、安定したば ね定数を示す床材であるといえる。

直張木質フローリング床の場合は、衝撃力が0〜200Nの場 合と $300 \sim 700 \mathrm{~N}$ の場合では大きく異なっている。0〜 200N の 場合では、 $0.7 \times 10^{5} \sim 3.4 \times 10^{5} \mathrm{~N} / \mathrm{m}$ を示し、その序列は表 1 に示すL值と対応している。しかし、300N～700Nの場合で は、0〜200Nの值に比べて、図10でわかるように、3〜8倍 のばね定数を示しており、非常に硬い床へと変化していること がわかる。これらの変化は、床衝撃音低减量として、予測值に 大きく関与するので、材料ごとに定量的表示が望まれる。

畳床は、2 層構造の化学畳が最も大きなぼね定数を示し、また、 特級本畳が、2 級本畳に比べて密度が大きいためか、ばね定数 が若干大きくなっているが、全体的にみて、衝撃力による変化も 比較的少なく、2.0 $2010^{5} \mathrm{~N} / \mathrm{m}$ 前後の值として扱い得るものと 考えられる。カーペット床は、当然のことながら、総厚やパイ ルの種類によってばね定数は変化し、衝撃力の関数として与え られる傾向にある。

また、図10によると、根太床と乾式二重床は、いずれの衝撃 力範囲でも 1.0 前後、畳休が 1.5 程度であるのに対して、直張 木質フローリング床とカーペット床は 2.0 以上の值となってい る。この値の大小によって非線形性の程度が推測でき、床仕上 げ構造の分類を行う際の一つ目安になるものと考えられる。

局部圧縮変形型の休である直張木質フローリング休、顋床、 カーペット床の動的ばね定数と床衝撃音レベル低減量との関係 を、図11に軽量衝撃源、図 12 に重量衝撃源の場合について示 す。このときの動的ぼね定数は、各床仕上げ構造の後述する衝 撃周波数を用いて、衝撃力を(1)式より算出し、その衝擊力に対 応するばね定数を用いて関係を求めた。

$\mathrm{F}=\mathrm{M} \cdot \mathrm{V}(1+\mu) \cdot \pi \cdot \mathrm{fn}$

ここで、 $\mathrm{F}$ : 衝撃力ピーク值 $(\mathrm{N}) 、 \mathrm{M}$ : 衝撃源の質量 $(\mathrm{kg}) 、$ $\mathrm{V}$ :衝突速度 $(\mathrm{m} / \mathrm{sec}) 、 \mu$ :反撥係数（ここで は 0.5 と仮定)、 $\mathrm{fn}:$ 衝撃周波数 $(\mathrm{Hz})$

なお、胃床やカーペット床のばね定数は、実際にはそれぞれ の床仕上げ構造毎にある範囲内に限定され、直張木質フローリ

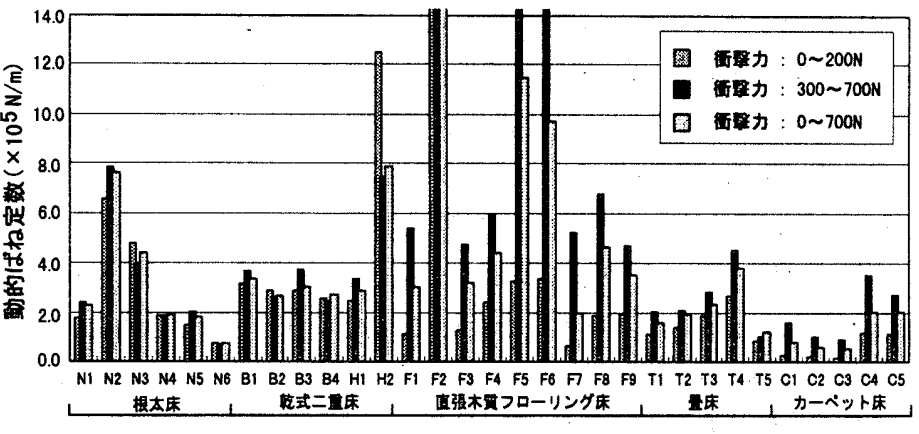

図 9 動的ばね定数算出結果

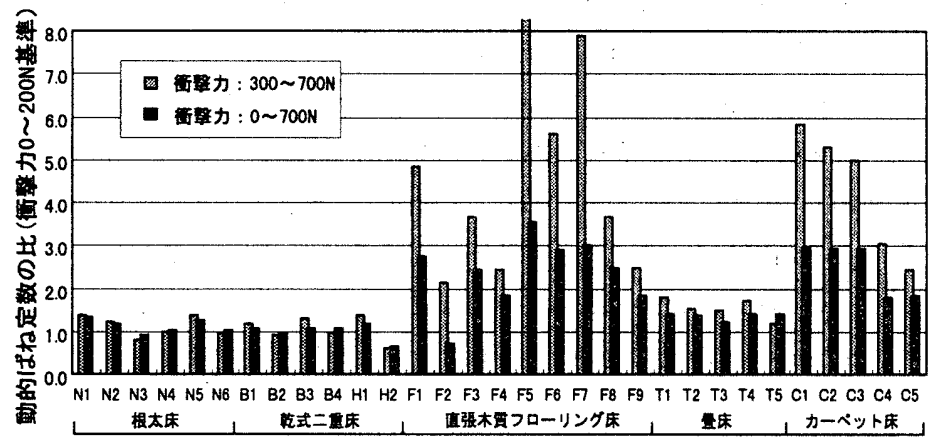

図 10 衝撃カ0〜200Nを基準にしたときの動的ばね定数の比

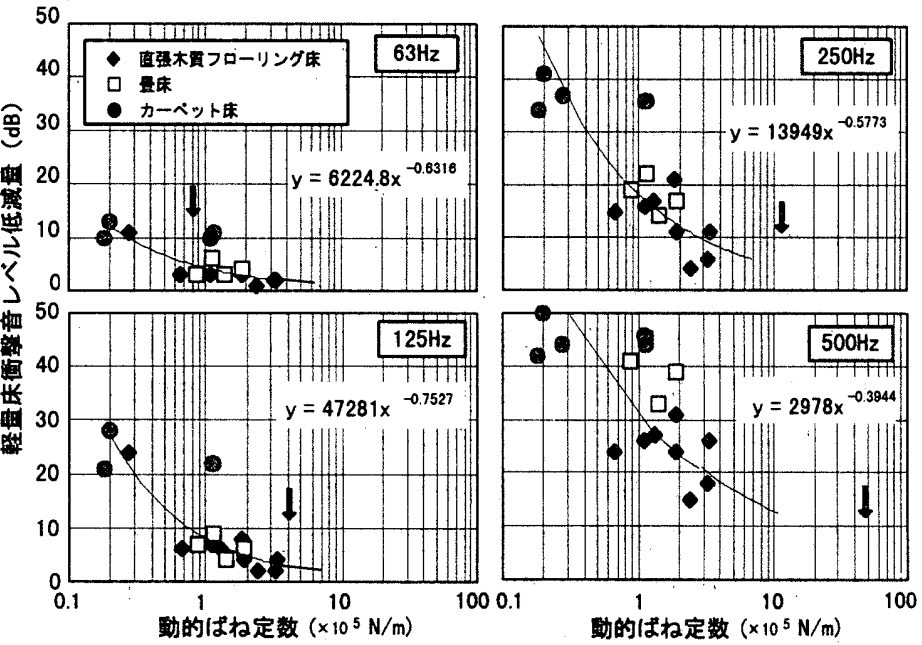

图11動的ばね定数と軽量床衝撃音レベル低減量との関係
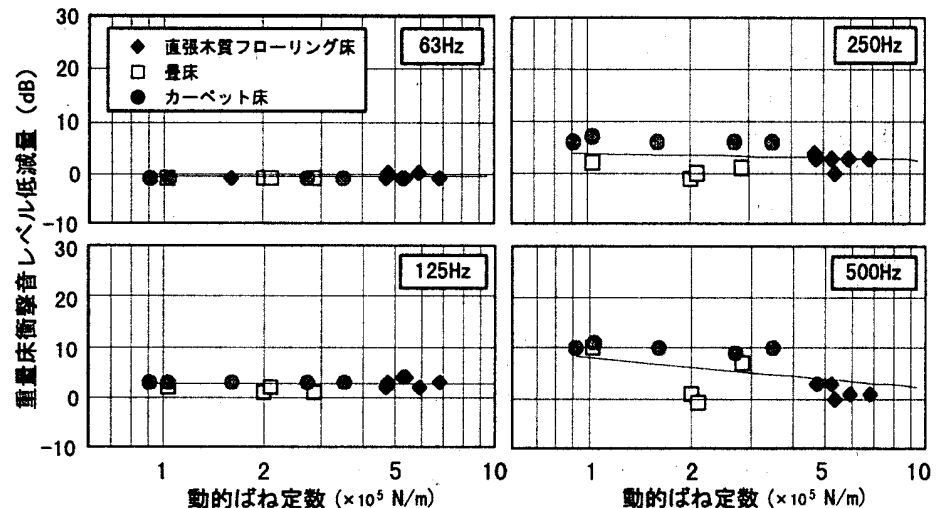

図12動的ばね定数と重量床衝撃音レベル低減量との関係 
ング床のように広範囲に分布するものではないが、ここでは、ばね 定数と低减量との関倸の大略をみるために、各床仕上げ構造を同じ グラフ上にプロットした。

床仕上げ構造の低減効果の有無は、基本的には、衝撃源側と床仕 上げ構造側のぼね定数の大小関係に依存する。軽量衝撃源のタッピ ングハンマーの等価ばね定数は、 $7.9 \times 10^{7} \mathrm{~N} / \mathrm{m}$ であり、直張木質フ ローリング床、疊床およびカーペット床のばね定数は、それと比べ て十分小さい値となっているので、軽量衝撃源に対しては、大きな 低减効果が期待できる。

図11中には、各オクターブバンド中心周波数が衝撃周波数とな る場合のばね定数を矢印で示した。これをみると、125Hz以上では、 矢印以下のばね定数の範囲で顕著な床衝撃音レベルの低下を示すこ とが確認され、その低減傾向は、図中に示した回帰式で大略推定可 能といえよう。

一方、重量衝軗源であるタイヤの等価ばね定数は、1.6×105 $\mathrm{N} /$ ஐであり、直張木質フローリング床、畳床、カーペット床のぼね定数 が、カーペットの一部を除き、これを上回っているため、衝撃特性 は床仕上げ構造によってほとんど変化しない。すなわち、床材が圧 密されて、衝撃力がそのまま入力されることになり、緩衝効果が得 られない結果となる。図12に示す重量床衝撃音レベル低減量をみる と、 $63 \mathrm{~Hz} 、 125 \mathrm{~Hz}$ では、低減効果はほとんど現れていない。なお、 $250 \mathrm{~Hz}$ 以上の周波数帯域で、床材のばね定数が、タイヤのばね定数 より小さい場合に若干効果が現れているのは、衝撃初期の衝撃力が 小さい場合に、表面材のばねが有効に作用し、床スラブへの伝達衝 撃力が低下するためと考えられる。

3.3 衝撃時間測定結果および衝撃周波数算出結果

タッピングハンマーによる衝撃時間測定結果を図13に示す。根太 床や乾式二重床は、4 msec 以下の衝撃時間になっているのに対し て、直張木質フローリング床の衝撃時間は、表面材が同じ板材でも 4〜8msecに延びている。これは、軽量床衝撃音の遮断性能を向上 させるために、緩衝材を裹打ちしたり、板材の内部に切り込みを入 れて断面欠損を生じさせ、曲げ剛性を低下させていることによると 考えられる。罡床は、図-3の低周波数域衝撃によるばね定数では、 表面にわらを用いている畳の特徴が現れていなかったが、軽量の タッピングハンマーによる衝撃では、表面層の影響により、衝撃時 間でははっきり差が現れ、表面材にわらを用いた畳は、表畳の下地 が木瀻維板の化学畳に比べて $2 \mathrm{msec}$ 程長い衝撃時間となっている。

衝撃時間 $(\Delta t)$ から、単振動系を仮定して衝撃周波数 $(\mathrm{f} n=1 /(2$. $\Delta \mathrm{t})$ ) を算出した結果を表 2 に示す。この衝撃周波数は、衝撃周波
数以上で緩衝効果が現れはじめることから、軽量床衝撃音遮断性能 を予測する上で重要である。衝撃力に正弦半波を仮定すれば、その 緩衝効果は、衝撃周波数の $2 \sim 4$ 倍の範囲で $15 \mathrm{~dB} /$ oct、それ以上の 高い周波数では $9 \mathrm{~dB} /$ oct 程度となる ${ }^{5)}$ 。

衝撃周波数 $(f n)$ を基準にして対象周波数 $(f)$ との比をとり、床仕 上げ構造別に軽量床衝撃音レベル低減量との関係を示すと図14のよ うになる。これによると、f/fnが 2 以上の場合は、直張木質フロー リング床とカーペット床はほぼ直線的に低減量が増加する傾向を示 すが、畕床は異なる傾向となっている。各床仕上げ構造別に低減量 の割合をみると、直張木質フローリング床は $10 \mathrm{~dB} / \mathrm{oct}$ 程度、カー ペット床は $12 \mathrm{~dB} /$ oct 程度となり、正弦半波の場合の $15 \mathrm{~dB} /$ octより 小さくなっている。これは、今回用いた衝撃力波形が図3に示すよ うに、2 段波形状となっているためと考えられる。これに対して、畳 床は、直張木質フローリング床やカーペット床のように一定の割合 で増加せず、非線形の增加傾向を示し、f/fnが 2 倍、 4 倍、8 倍に なる毎に、それぞれ低減量の増加分が $5 、 10 、 15 \mathrm{~dB}$ 前後となり、 $5 \mathrm{~dB}$ ずつ低隇量の増加分が上乗せになる傾向を示している。これらのこ とから、同じ局部圧縮変形型の床でも、各床仕上げ構造には、衝撃 力に対する変形応答特性に相違があることが窥われ、この相違が、

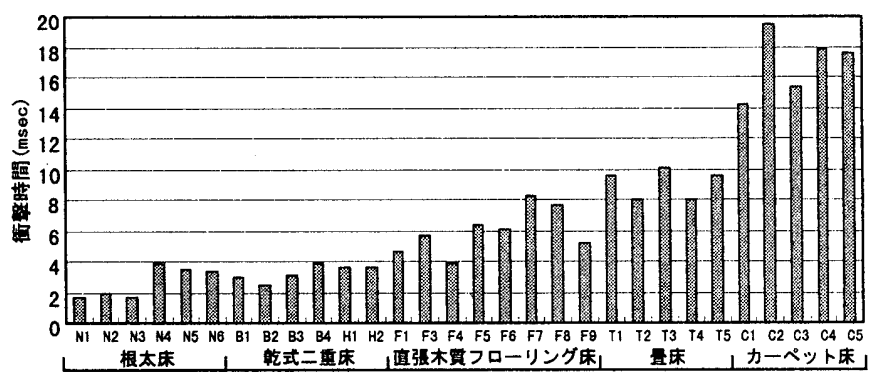

図13 衝撃時間測定結果

\section{表2 衝撃周波数算出結果}

\begin{tabular}{|c|c|c|c|c|c|c|c|c|}
\hline & & 语慗周波数 & & & 征罍周波数 & & & 酎整周波数 \\
\hline 蕰 & $F-1$ & 107.8 & \multirow[b]{2}{*}{ 乾 } & $B-1$ & 166.7 & & $N-1$ & 292. 4 \\
\hline 與 & $F-3$ & 89.0 & & $B-2$ & 208.3 & & $\mathrm{~N}-2$ & 256.4 \\
\hline 霄 & F-4 & 127.9 & \multirow{2}{*}{$\begin{array}{l}\text { 式 } \\
\text { 更 }\end{array}$} & B-3 & 163.9 & & $N-3$ & 292. 4 \\
\hline 7 & $F-5$ & 78.7 & & B-4 & 129.9 & \multirow{3}{*}{$\begin{array}{l}\text { 太 } \\
\text { 㦿 }\end{array}$} & $N-4$ & 127.9 \\
\hline 1 & F-6 & 82. 0 & \multirow[t]{2}{*}{ 床 } & $H-1$ & 136.6 & & $N-5$ & 146. 2 \\
\hline ני & $F-7$ & 60.2 & & $\mathrm{H}-2$ & 136.6 & & $\mathrm{~N}-6$ & 146.6 \\
\hline H & $F-8$ & 66.1 & \multirow{5}{*}{$\begin{array}{l}\text { 量 } \\
\text { 床 }\end{array}$} & $T-1$ & 52.5 & \multirow{2}{*}{ 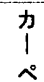 } & $c-1$ & 35.3 \\
\hline 休 & $F-9$ & 97.5 & & $T-2$ & 62.0 & & $c-2$ & 25.6 \\
\hline & \multirow{3}{*}{\multicolumn{2}{|c|}{ 単位: Hz }} & & $T-3$ & 50.0 & \multirow{3}{*}{$\begin{array}{l}\text { 卜 } \\
\text { 床 }\end{array}$} & $c-3$ & 32.5 \\
\hline & & & & $T-4$ & 62.0 & & $c-4$ & 28.1 \\
\hline & & & & $T-5$ & 52.5 & & $c-5$ & 28. 4 \\
\hline
\end{tabular}
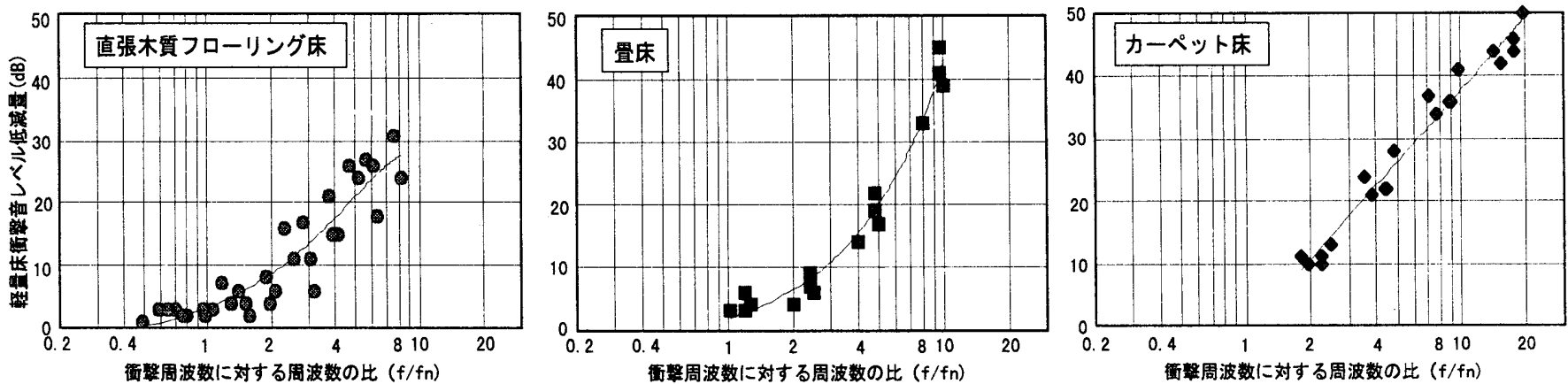

図14 局部圧縮変形型床の衝擊周波数を基準とした対象周波数の比と軽量床衝撃音しベル低隇量との関係 
衝撃時の衝撃力波形の変化による周波数特性の違いとして現れたも のと推測される。なお、低減量絶対值は、衝盤周波数の 4 倍に相当 する周波数で、直張木質フローリング床と畳床は $15 \mathrm{~dB} 、$ カペット 床は $20 \mathrm{~dB}$ 程度となっている。

このことから、軽量床衝撃音レベル低減量を大きくするためには、 衝撃時間を長くし、衝擊周波数を低くするのがより効果的になるこ とがわかるが、質系床材で、床がやわらかになりすぎると、歩行感 などが悪くなって居住性の面で問題となってくるので、適正なかた さを確保した上で、床衝撃音遮断性能を向上させることが要求され よう。

\section{4 駆動点インピーダンス測定結果}

駆動点インピーダンスは、躯体スラブの床衝撃音レベルを予測す る上で重要な物理量となっているが、床仕上げ構造の低減量を予測 する際にも有効になるものと考えられる。

床仕上げ構造に単振動系を仮定すると、そのインピーダンスは、 （2）式により求められ、図15のような特性となる。

$Z=r+j(\omega m-k / \omega)$

ここで、 $\mathrm{r}$ : 抵抗、 $\omega$ : 角周波数、 $\mathrm{m}$ : 質量、 $\mathrm{k}$ : ばね定数

固有周波数付近で共振によるインピーダンスの低下が生じ、それよ り低域ではばねによるインピーダンスが支配的となって-6dB/oct、 それより高域では質量によるインピーダンスが支配的となって十 $6 \mathrm{~dB} /$ oct の特性を示す。また、抵抗が大きくなると共振領域での低 下が抑えられるとともにインピーダンスレベルの勾配が緩やかな特 性となる。

各床仕上げ構造の駆動点インピーダンス測定結果を図16に示す。 比較のために示したコンクリートスラブ上に直張した長尺塩ビシー トのインピーダンス特性は、その接着躯体である均質単板のコンク リートスラブのインピーダンス特性に依存する特性を示し、共振、 反共振を繰り返しながら床スラブの駆動点インピーダンスに収束す る特性を示している。ちなみに、(3)式により求めた衝撃インピーダ ンスレベル Lz は、 $250 \mathrm{~mm}$ 厚で $121 \mathrm{~dB} 、 170 \mathrm{~mm}$ で $114 \mathrm{~dB}$ となる。
$\mathrm{Lz}=20 \log _{10}\left(2.31 \rho \cdot \mathrm{cl} \cdot \mathrm{h}^{2}\right)$

ここで、 $\rho:$ スラブの密度、 $\mathrm{cl}:$ : ラブ内の縦波の伝搬速度、

$$
\mathrm{h}: \text { スラブの厚さ }
$$

一方、各床仕上げ構造のインピーダンス特性は、長尺塩ビシート の場合と明らかに異なって、図15に示した単振動系のインピーダン ス特性に近似した傾向を示し、それぞれの床仕上げ構造の違いが はっきり現れている。

各床仕上げ構造別にみると、直張木質フローリング㦿の場合の周 波数特性は、各床仕上げ材ともほほ同じ傾向を示しているが、イン ピーダンスレベルの大きさは、大きく異なり、ばね定数の変化に対 応した值を示している。共振周波数は、100Hz 以上の比較的高域に あらわれており、これが、床仕上げ構造の床衝撃音レベル低減量を 決定する重要な特性となる。なお、衝般力 $300 〜 700 \mathrm{~N}$ のきの動 的ばね定数kに基づき算出した $10 \mathrm{~Hz}$ におけるばねインピーダンスレ ベル $\left[\mathrm{Lz}=20 \log _{10}(\mathrm{k} / \omega)\right]$ は、図 17 に示すように、実測値に大略近 似する傾向を示している。なお、F-4、F-9が他の床材と異なり、実測 值の方が大きくなっているのは、緩衝材の厚さや材質などの関係で、 衝撃時の床材の圧密の程度が他の床材より大きくなり、インピーダ ンスが上昇したものと考えられる。

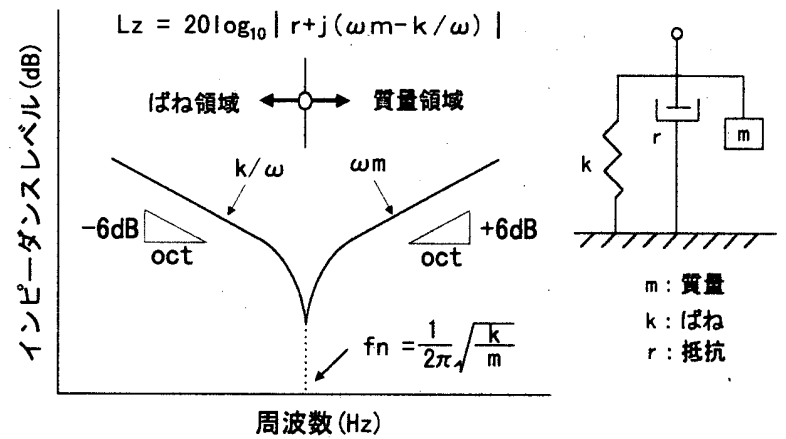

図15 インピーダンス特性のモデル
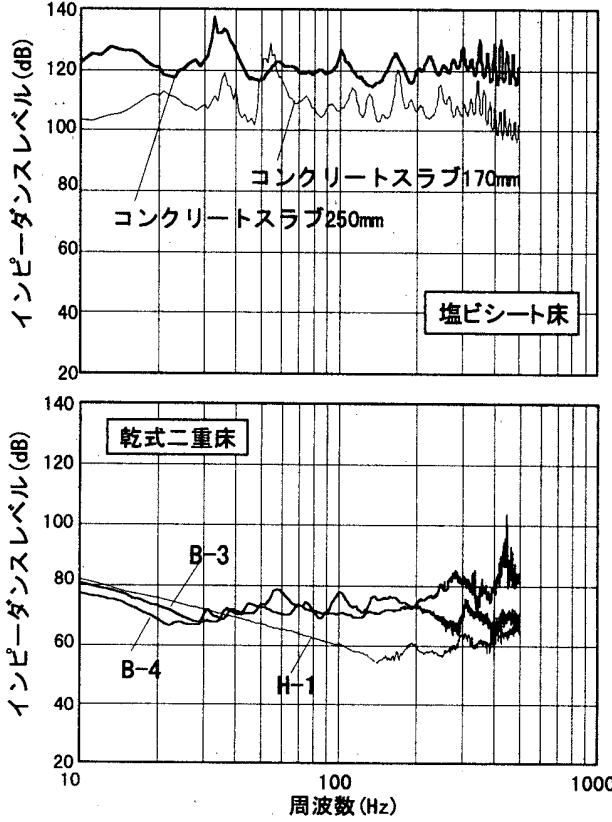
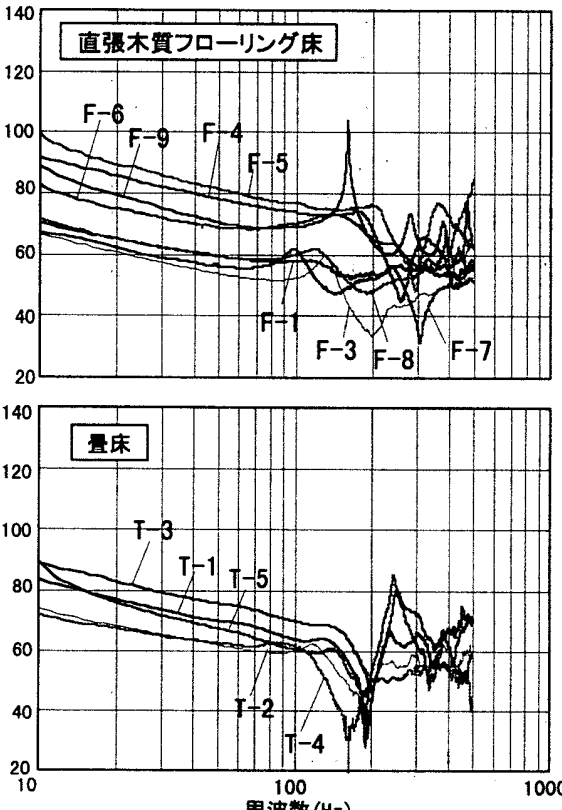

周波数 $(\mathrm{Hz})$

図16 取動点インピーダンス測定結果
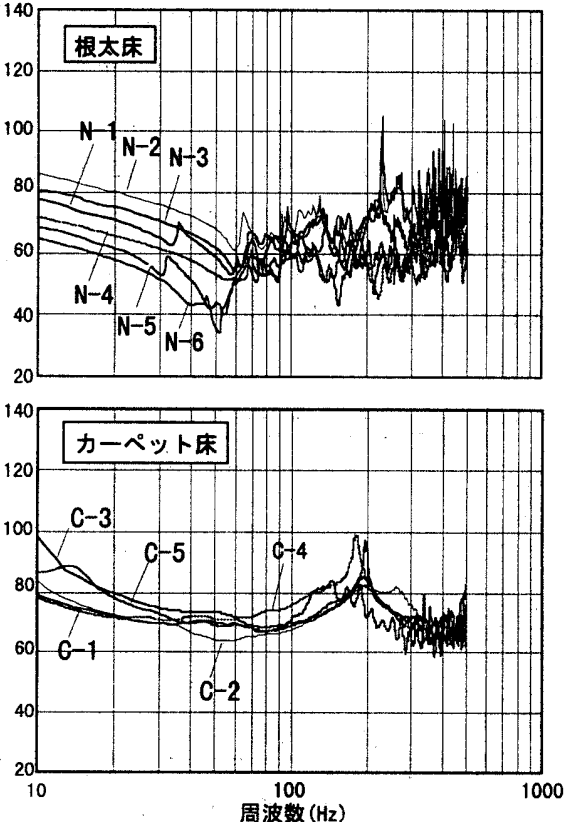
根太床のインピーダンス特性は、大引き、根太を含む根太床構 造としての共振周波数が $30 \sim 60 \mathrm{~Hz}$ に、根太間の合板の質量と曲げ ばねによる共振が、 $125 \mathrm{~Hz}$ 帯域を中心とする周波数に現れている。 低域におけるインピーダンスの変化の割合は、ほぼー6dB/oct と なっており、10Hz におけるインピーダンスレベルも、図 18 に示 すように、0〜 700N の衝撃力におけるばね定数に基づき算出し た値にほほ一致している。また、 $200 \mathrm{~Hz}$ 付近以上の周波数領域にお いては、質量に依存するインピーダンス特性になっているとみる ことができる。床衝撃音遮断性能の面からみると、 $125 \mathrm{~Hz}$ 帯域付近 の共振周波数が問題となり、根太床構造の改善のポイントになると 考えられる。

乾式二重床は、防振ゴム置床と発泡プラスチック下地床では明 らかに異なるインピーダンス特性を示している。B-3、B-4 の防 振ゴム置床は、ばねで支配されるインピーダンスの周波数領域は $20 \mathrm{~Hz} \sim 30 \mathrm{~Hz}$ の低域にとどまっており、それ以上の周波数領域で はインピーダンスがー定值となって、むしろコンクリートスラブ のような均質板的特性を示している。これは、支持脚部のゴムの ばね定数が合板部の曲げばね定数を下回っているためであり、浮 床構造的な特性を示している。また、今回用いた試験体は、上部 合板部に種々の制振材を用いて複層構造化しているため、共振增 幅もほとんどみられないのが特徵で、 $63 \mathrm{~Hz}$ 以上の床衝撃音遮断 性能の向上が期待できる床仕上げ構造といえる。なお、軽量床衝 揧音レベル低減量測定結果では、 $63 \mathrm{~Hz}$ で $10 \mathrm{~dB}$ の低減量が得られ ている。発泡プラスチック下地床の H-1 は、発泡プラスチックの 局部ばねの影響が現れ、マス・ばね系を構成している特性を示し ているが、共振周波数は $150 \mathrm{~Hz}$ 程度と高くなっている。これは、 根太床の曲げばねとは異なり圧縮ばねとなるためと考えられる。 このことは、 $125 \mathrm{~Hz} \sim 250 \mathrm{~Hz}$ 帯域において床衝撃音遮断性能の 低下が生じる可能性があることを示している。

畳床は、基本的には、単振動系の振動特性を示しているが、化学 畳であるT-2、T-4 は、 $-6 \mathrm{~dB} /$ octより緩やかな勾配となっており、 系の抵抗が大きいことがわかる。基本構造は化学畳と同様の構造で あるが、表面にわらを用いているT-1は、インピーダンス特性でみ ると、むしろ本畳に近い特性を示しており、本畳と化学畳という分 類のほかに、表面にわらを使用している否かによる分類方法もある と考えられる。いずれの畳床とも反共振による增幅が $250 \mathrm{~Hz}$ 付近に あらわれているが、本畳 $(T-3, T-5)$ は急峻で、化学畳のように層状 構造の畳(T1、T2、T4) は緩やかになっている。これは、層状構造の盢 は層状化により損失が増大するためと考えられる。また、質量が支 配的となる高域では、平坦なインピーダンス特性を有する結果と なっており、根太床などとは異なり周波数の関数として説明できな い傾向がみられる。これは、有効質量の特定が難しいこと、周波数 の増加とともに質量の低下が生じていることが原因と考えられる。 なお、動的ぼね定数から算出したインピーダンスレベルは、表面材 がわらで構成されている畳は実測值との差が大きくなる傾向がでて いる。

水平方向の力の伝達が無視できるカーペット床は、ばねと質量が 他の床材に比べて特定できない床材といえるが、参考のためイン ピーダンス特性の測定を行った。低域におけるインピーダンス特性 は-6dB/octとなっているが、高域の特性は、畳床にみられたイン

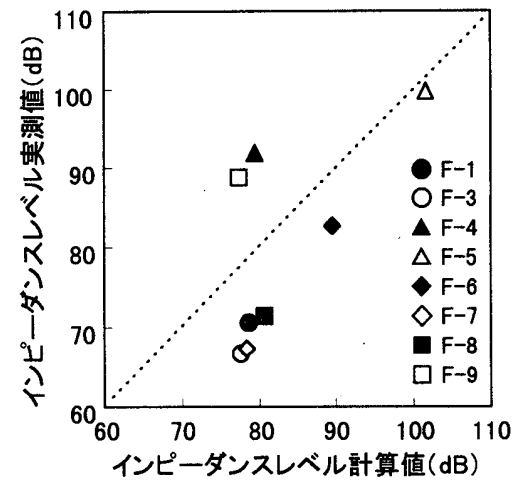

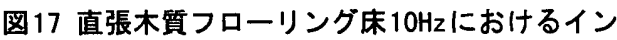
ピーダンスレベルの実測値と計算值との対応

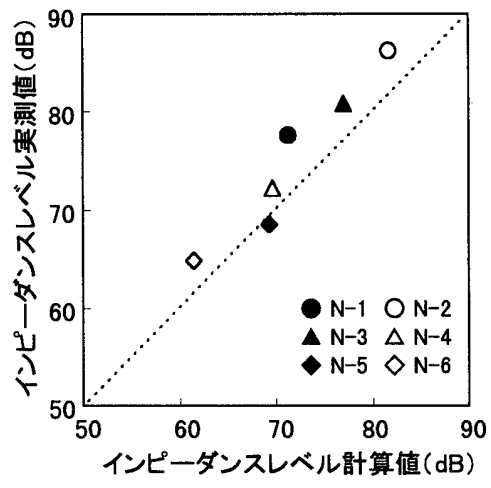

図18 根太床 $10 \mathrm{~Hz}$ におけるインピーダンスレベル の実測値と計算値との対応

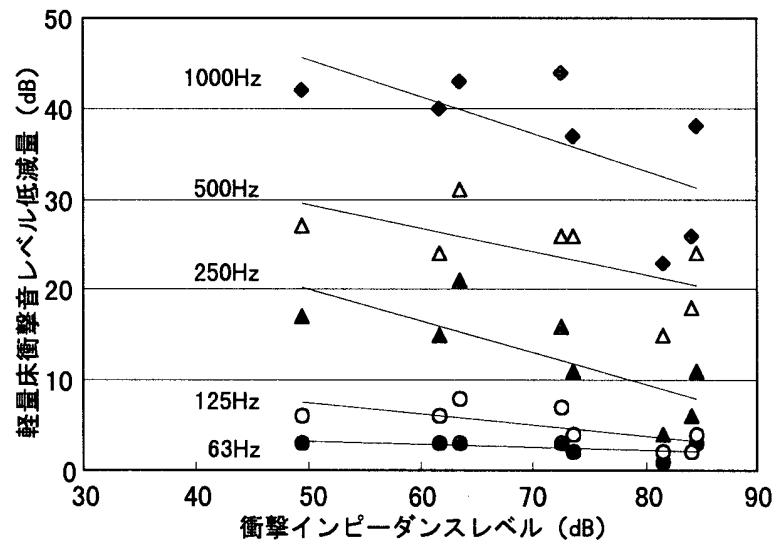

図19 直張木質フローリング床の衝撃インピーダンス レベルと軽量床衝撃音レベル低減量との関係

ピーダンス低下の傾向がさらに顕著となっている。これらのカー ペット床は、フェルト下地として施エしているため、カーペットと フェルトの二重構造のインピーダンス特性が現れているとも解釈で きそうである。

以上みてきたように、駆動点インピーダンス特性には、床仕上げ 構造の特徵がはっきり現れることから、床仕上げ構造の分類に有効 な物理量であるといえる。

床衝撃音の面からは、各床仕上げ構造の衝撃周波数がばね領域に 相当するか、質量領域に相当するかで振動系の評価が異なり、ばね 
領域に相当する場合は、単純なぼねとしての取り扱いとなり、質量 領域に相当する場合は、二重構造としての取り扱いとなる。先に算 出した衝撃周波数との関係をみると、直張木質フローリング床、畳 床およびカーペット床は、タッピングハンマーによる衝撃に対して は単純ばねの振動系であることが確認できる。

試験体の種類によってインピーダンスレベルの変化が大きい直張 木質フローリング床について、衝撃インピーダンスレベルと軽量床 衝撃音レベル低減量との関係を求めた結果を図19に示す。これによ ると、周波数にようて低減量の変化の割合は異なるが、各周波数と も衝撃インピーダンスレベルが小さくなると、軽量床衝擊音レベル 低減量は直線的に大きくなる結果が得られている。250Hz以上の周 波数では、衝撃インピーダンスレベルが $10 \mathrm{~dB}$ 低下すると低減量は 3 $\sim 4 \mathrm{~dB}$ 上昇する傾向となっている。これは、局部圧縮変形型の床の ような単純ばね系の床材に限られた特性と考えられるが、衝撃イン ピーダンスレベルを知ることにより、軽量床衝撃音レベル低減量を 予測することが可能であることが示唆されている。

\section{4. まとめ}

今回の実験的検討から、次のようなことが明らかとなった。

1）動的変位量の衝撃力による変化、動的ばね定数などの測定結果 より、床仕上げ構造の線形、非線形の判定が可能となった。これは、 床仕上げ構造を分類する上で有効である。また、床衝撃音レベルの 予測計算においては、衝撃力に対応するぼね定数を知る必要がある ことが示された。

2）駆動点インピーダンス特性より、明確な質量を有しないカーペッ 卜床を除く床仕上げ構造の振動特性は、高域における共振増幅を無 視すれば、基本的には単振動系の振動応答現象として捉えることが でき、この周波数特性により、床仕上げ構造の特徽が把握できる。

3）動的ばね定数と局部圧縮変形型の床の軽量床衝撃音レベル低减 量との関係は、指数関数的であり、ばね定数を知ることによって、床 衝撃音レベル低減量の予測が、ある程度可能であることが示された。 4）衝撃周波数を基準とした対象周波数の比と軽量床衝辑音レベル 低減量との関係は、変形形態が同じ局部圧縮変形型の床でも異なる 傾向を示し、床仕上げ構造によって衝撃力に対する変形応答特性に 相違があることが示された。すなわち、直張木質フローリング床は $10 \mathrm{~dB} /$ oct、カーペット床は $12 \mathrm{~dB} /$ oct、畳床は、衝撃周波数との比 が 2 倍になる毎に、低減量の增加分が上乗せになっていく傾向がみ
られる。

5）衝撃インピーダンスレベルと軽量床衝撃音レベル低减量との関 係は、単純ばね系の床材の場合は、衝翚インピーダンスレベルが低 下すると低減量は直線的に上昇する傾向を示す。

今回の実験的検討から、各種床仕上げ構造の振動応答特性を把 握するとともに、局部圧縮型の変形を示す休仕上げ構造に関し て、掁動応答特性から得られる物理量と軽量床衝慗音レベル低減 量との関倸を明らかにすることができた。

今後、さらにデータの蓄積を行うとともに、根太床、乾式二重床 の場合に関しても検討し、床仕上げ構造の床衝撃音レベル低減量の 実務的な予測法の確立へと慗げていくつもりである。

最後に、実験、解析にご協力を頂いた鉄建建設平光厚雄氏、日本 大学大学院生矢後佐和子氏、日本大学理工学部の平成 8 年度卒論生 の方々ならびに戸田建設技術研究所松岡明彦氏に謝意を表します。

\section{【参考文献】}

1) 木村翔、井上勝夫、新井昭義 :「床衝擊時における床スラブインピー ダンス特性の予測手法に関する研究」日:本建築学会計画系論文集、第 365 号 (1986 年 5 月) $P 1-P 8$

2) 井上勝夫、木村翔、中澤真司 :「インピーダンス法による床衝繋音レ ベル予測手法検証のための実験的研究」日本建築学会計画系論文集、第 407 号 (1990年1月) P1-P9

3）井上勝夫、木村翔、宮崎浩司: 「木質系床構造の重量衝慗源に対する 床衝撃音低減方法に関する研究」日本建築学会計画系論文集、第 382 号 （昭和 62 年 12 月） P1-P9

日本建築学会大会学術講演梗概集、昭和 60 年 10 月 $\quad$ P179-P180 4）木村翔、井上勝夫、尾崎充男 :「鉄骨ALC系住宅における重量衝揫音 遮断性能の改善に関する研究」日本建築学会計画系論文集、第 496 号 （1997 年6月） P15-P21

5)安岡正人：「床衝撃音防止設計法」音響技術 N0.20，1977.10

6) 井上勝夫、木村翔、前原暁洋、渡辺秀夫:「床弾性試験用衝撃源の試作 と住宅床の振動応答特性(歩行感からみた住宅床の振動応答特性と床衝 撃音遮断性能に関する研究 その 2)」日本建築学会計画系論文集、第 483 号 (1966 年 5 月) $\quad \mathrm{P} 9-\mathrm{P} 15$

7）井上勝夫、木村翔、平光厚雄、矢後佐和子、渡辺秀夫:「歩行感加見 た住宅床の感覚評価に関する研究(歩行感からみた住宅床の振動応答特 性と床衝撃音遮断性能に関する研究 その 3 )」日本建策学会計画系論 文集 第 504 号（1998年 2 月） 